Information for citation:

Kharitonova Yu. S. Pravovye mekhanizmy sozdanija i zashity imidzha kommersanta [Legal Mechanisms for Formation and Protection of the Corporate Image]. Vestnik Permskogo Universiteta. Juridicheskie Nauki - Perm University Herald. Juridical Sciences. 2016. Issue 34. Pp. 451-460. (In Russ.). DOI: 10.17072/1995-4190-201634-451-460.

UDC 346.16

DOI: $10.17072 / 1995-4190-2016-34-451-460$

\title{
LEGAL MECHANISMS FOR FORMATION AND PROTECTION OF THE CORPORATE IMAGE
}

\section{Yu. S. Kharitonova}

The Russian State University of Justice (RPA of the Ministry of Justice of Russia)

2, Azovskaya st., Moscow, 117638, Russia

Moscow Academy of Economics and Law

23, Varshavskoye shosse, Moscow, 117105, Russia

ORCID: 0000-0001-7622-6215

ResearcherID: K-7495-2016

e-mail: pravo-biznes2015@yandex.ru

Introduction: recognized by economists and researchers in other social sciences, the value of the corporate image (or image of a business proprietor) is almost completely negated by jurists. The necessity to protect the corporate image, which has recently appeared in practice, entails the need to study this concept based on the existing legislation. Purpose: based on interdisciplinary research, to reveal the peculiarities of the Russian legal mechanisms for creation and protection of the corporate image. Methods: the methodological framework of the research is based on a set of general scientific and specific scientific methods: dialectical, comparative legal, historical, formal-legal and linguistic ones. Results: the author has revealed some specific features of the Russian system of measures for creation and protection of the corporate image, which are not only found in traditional institutions of the intellectual property right but also reflected in public legislation. Conclusions: the term "image" is increasingly used by the legislators and courts to refer to intangible assets of companies and sole proprietors, which shows the necessity to recognize it as an independent legal concept. In modern conditions, for creation and protection of an image (including elements of reputation, corporate identity) it is possible to use different procedures for forming brand identity (primarily trade names, trademarks, commercial symbols), institutions of intellectual property, and also measures to maintain market competition based on competition law.

Keywords: image; intellectual property; brand identity; business reputation; protection of competition

\section{Information on Russian}

\section{ПРАВОВЫЕ МЕХАНИЗМЫ СОЗДАНИЯ И ЗАЩИТЫ ИМИДЖА КОММЕРСАНТА}

\section{Ю. С. Харитонова}

Доктор юридических наук, профессор

Всероссийский государственный университет юстиции (РПА Минюста России)

117638, Россия, г. Москва ул. Азовская, 2 корп. 1

(C) Kharitonova Yu. S., 2016 
главный научный сотрудник

Московская академия экономики и права

117105, Россия, г. Москва, Варшавское шоссе, 23

ORCID: 0000-0001-7622-6215

ResearcherID: K-7495-2016

e-mail: pravo-biznes2015@yandex.ru

Введение: признанная экономистами и представителями иных общественных наук цุенность имиджа коммерсанта практически полностью отрицается правоведами. Появление в практике потребности защзтить имидж предпринимателя влечет необходимость исследования данного понятия с опорой на действующее законодательство. Цель: на основе междисииплинарного исследования выявить особенности российских правовых механизмов создания и защиты имиджа коммерсанта. Методы: при проведении исследования использовались как общенаучные, так и частнонаучные методы исследования: диалектический, сравнительно-правовой, исторический, формально-юридический, лингвистический. Результаты: выявлены особенности российской системы мер создания и возможной защчиты имиджа предпринимателя, которые не только обнаруживаются в традиционных институтах права интеллектуальной собственности, но и отражены в публичном законодательстве. Выводы: термин «имидж» все чащзе применяется законодателем и судами для обозначения нематериального актива компаний и индивидуальных предпринимателей, тем самым демонстрируется необходимость признания данного понятия в праве как самостоятельного. В современньх условиях для формирования зашчиты имиджа (включая элементы репутации, фирменного стиля) могут использоваться процедуры создания средств индивидуализаџии (прежде всего фирменных наименований, товарных знаков, коммерческих обозначений), институты авторского права, а также меры защиты конкуренции на основании антимонопольного законодательства.

Ключевые слова: имидж; интеллектуальная собственность; средство индивидуализации; деловая репутация; защита конкуренции

\section{Introduction}

According to Wikipedia, an image (from Latin: imago) is an artificial representation formed in a social or individual conscience by the mass media and psychological devices. An image is created by public relations, propaganda, and advertising with the aim of formation in a social conscience of a certain attitude towards an object. An image can possess both real traits of the object and those not existing and just ascribed ${ }^{1}$.

Different definitions ${ }^{2}$ of the concept given in encyclopedias have a common feature, which is reference to the fact that an image is always a representation of somebody or something. In management, an image is often defined as a spontaneous or deliberately created impression of a personality or a social structure. Several considerations of the concept have been worked out in science. These are economic [2;17], sociological

\footnotetext{
${ }^{1}$ Available at: https://ru.wikipedia.org (accessed 25.07.2016).

${ }^{2}$ Available at: http://dic.academic.ru/dic.nsf/enc3p/138110 (accessed 25.07.2016)
}

[11] and psychological [14] interpretations, the latter even having given rise to a new applied science, imageology.

A corporate image develops and exists regardless of whether or not some deliberate efforts are made [20] and is often treated by specialists as a spontaneous phenomenon $[19 ; 30]$. This means that in the case a company's image is constantly and thoroughly worked at, the firm's competitiveness increases (it can afford employing the best specialists and create positive impression in the consumers' mind); if this is not the case, which is not rare, the company's future can be threatened or even destroyed [1]. However, the concept of the corporate image is seldom mentioned in statutory acts and law enforcement practice does not bring up the issues of protection of the image and regulation of relations concerning its development.

\section{Corporate Image as a Tool of Competition}

Corporate identity, means of corporate individualization and so-called "feedback", i. e. corporate 
communications, are considered in foreign literature to be the main constituents of the corporate image. Corporate identity makes the company unique and helps to create a peculiar personality of the enterprise. Corporate communications are a set of sources, messages, and other information presented in the mass media through which the company expresses its identity or brand for different groups of its target audience. Thus, a corporate image is consumers' impression of the company. In many cases, the idea of business as personified property $[21 ; 22]$ is used to explain the fact that the company possesses an image and so do its management, goods produced and services provided. The corporate image concept also includes reputation of the company [20].

Marketing and intellectual property law are deeply interconnected, which was noticed and emphasized by one of the well-known specialists in the field S. A. Sudarikov. He came to a conclusion about the necessity to introduce a concept of "marketing designations" to mark manufactured goods supplied to the market; these are a trade name, trademark, place and indication of the product's origin, domain name. Protection of marketing designations appears to be part of the intellectual property system since these are used to mark products in which creative items of intellectual property are represented [15].

Nowadays, it is becoming obvious that corporate image is the crucial factor in a company's competitiveness, its attractiveness as an employer, and stock value [4]. Image influences almost all aspects of the company's functioning.

Thus, economics gives general directions for the development of the legal model of the corporate image protection. Since application of economic terms is not common in the current legal practice, law enforcers have to fit the factual relation emerging into the existing statutory concepts.

For instance, an internal image of a company correlates with adoption of various ethical codes and observance of labor discipline within companies. Both the visual corporate image and the image of a product appear to be under the regulation of the rights to means of corporate individualization as well as rules of fair competition.

\section{Legal Mechanisms \\ for the Corporate Image Development}

In practice, development of a corporate image is often connected with the design and use of different designations being protected as intellectual property. Identification of a company and its goods, works, and services takes place through creation of a unique design, branding, and use of trademarks and other elements of brand identity (means of individualization) [29]. That is why violation of the right to the trademark or name of a legal person is often considered an offence against its image and reputation.

According to S. A. Sudarikov, marketing designations are indications of marketplace participants, in particular manufacturers and their goods, companies or individuals providing services (social, transport, financial, innovative, investment, consulting, etc.) [15]. Here it should be emphasized that legal practice has seen some examples of mentioning corporate image and identity in the context of transferring rights to them. At the same time, according to an act of the Supreme Court of the Russian Federation, although objects and information carrying image and style can be transferred under a contract the same as items of intellectual property, such a contract is not necessarily a commercial concession ${ }^{1}$. Thus, we see that legal practice admits the existence of public relations concerning corporate image and identity.

However, it is a problem of the current law enforcement practice that the nature and character of the information determining corporate identity and image have not been defined. It should be noted that trademark and brand do not always completely cover the concept of image. In other words, there is no holistic approach to the image, which is traditionally treated through the prism of such legal notions as items of intellectual property, trademarks, know-

\footnotetext{
${ }^{1}$ Decision of the Supreme Court of RF of August 26, 2015 No. 304-es15-5828 on case No. A45-13334/2014. [Electronic resource]. Access from the information system "Judicial and Statutory Acts of the Russian Federation".
} 
how, information of industrial, technical, economic, organizational type, etc.

There is another legal object worth being discussed, which is a so-called "Brand Book". It is a set of rules and examples of how to apply corporate identity with regard to the use of the logotype, color layout and design elements, fonts, documents and business cards, letterhead, company stickers, seal imprints, dress code and interior elements, signboards. According to the Civil Code, the following items presented in a "Brand Book" are among items of intellectual property under protection: logotype, design of documents and signboards, fonts, business cards, seal imprints, clothes, and interior, individualization means (trade name and commercial designations - these on signboards, forms, bills and other documents, in advertisements, on goods and their packaging, on the Internet), as well as trademarks which are to be registered.

Consideration of some elements of corporate identity in terms of law allows us to draw the following conclusions.

A trade mark and logotype as the basis of corporate identity are not acknowledged in Russia as selfsufficient objects of law. According to some publications, a logotype is a specially designed, stylized, and shortened form of a company's name often presented in its original pattern. As a rule, a logotype consists of 1) a trade name or its part; 2) indication of the business sphere; 3) pictorial elements (pictures, geometric figures, special graphic images, various colors). Consequently, a logotype can include several registered trademarks or even a trade name, which is an object of legal protection [6]. The picture used as a logotype may not contain the trademark. In court practice, a company's logotype is often not regarded as an intangible asset. There is another opinion according to which a logotype is defined as a non-registered in the Office of Intellectual Property of the Russian Federation original pattern of the full or shortened name of a company (its services or product group) that is specially designed to attract consumers' attention ${ }^{1}$.

In practice, legal issues usually arise in the context of violation of the rights to trademark registered in the Russian Federation through the use of a

\footnotetext{
${ }^{1}$ Decision of the Federal Arbitration Court for the Moscow Circuit of June 22, 2009 № KA-A40/5426-09 on case № A40 41784/08-98-123. [Electronic resource]. Access from the information system "Judicial and Statutory Acts of the Russian Federation".
}

logotype (image) confusingly similar to a competitor's trademark ${ }^{2}$.

A logotype can be protected as an item of intellectual property but it is normally not of creative origin, which is required by the rule of providing legal protection (Art. 1259, Civil Code of the Russian Federation).

At the same time, in statutory acts a logotype is often associated with a company's advertising. For example, according to explanations by the Ministry of Finance of the Russian Federation ${ }^{3}$, expenditure related to designing a logotype is acknowledged as the company's expenditure and can be taken into account as advertising expenses (on the grounds of Sub-clause 28, Cl. 1, Art. 264 of the Tax Code of the Russian Federation).

From a legal perspective, corporate identity can also be represented by both intellectual property items and elements of brand identity (means of individualization). These include the company's corporate colors and elements of design distinctive for the company, its products, clothing and interior.

In the majority of cases, color is not regarded as an independent means of individualization, neither it can be considered an intellectual property item. However, businessmen have recently started the search for legal mechanisms to protect their unique style, including color being treated as trademark.

For example, Vanish has become the holder of a right to purple color among stain removers; among companies dealing with building and thermal insulating materials, the right to orange color belongs to "Penopleks"; "Vimpelkom" has been exclusively entitled to use the combination of black and yellow since 2006 .

Until recently, registration of a certain color as an individual trademark has been criticized as an unfair advantage of one company over another [31]; but now such a procedure is possible even in Russia $^{4}$ [24]. The Russian Federal Service for Intel-

\footnotetext{
${ }^{2}$ Decision of the Supreme Court of the Russian Federation of August 17, 2015 No. 306- es 15-8961 on case № A49-3204/14. [Electronic resource]. Access from the information system "Judicial and Statutory Acts of the Russian Federation".

${ }^{3}$ Letter of the Ministry of Finance of the Russian Federation of September 12, 2014 No. 03-03-06/1/45762 [Electronic resource]. Access from the information system "Ayudar Info".

${ }^{4}$ According to W. Cornish, it is quite possible that several requests will cover all the colors used for a certain product, which will deprive competitors of the opportunity to sell products in any packaging except for uncolored (Cornish W. R. Intellectual Property. London, 1996. P. 589). Ex-
} 
lectual Property has registered red, green and blue colors as trademarks of MTS, Sberbank, and "Gazprom" respectively, and doing so it recognized color as "an important mean in brand individualization". It is not just a color, but a particular tone that is assigned to each company: green Pantone $349-$ to Sberbank, red Pantone 485 - to MTS, and blue Pantone 300CV - to "Gazprom". The trademarks of the corporations mentioned have been registered in accordance with the legislation on different classes of the International Classification of Goods and Services.

The concept of corporate identity is mentioned in competition law. Article 14.6 of Federal Law No. 135 of July 26, 2006 "On Protection of Competition"1 (hereinafter referred to as Competition Protection Law) does not allow for unfair competition arising in the case when an economic entity performs activity (or inactivity) which could cause the confusion with a rival economic entity's activity or with goods or services placed into the stream of commerce in the territory of the Russian Federation by a rival economic entity, including copying or imitation of the visual appearance of a product being placed into the stream of commerce by a rival economic entity, the product's packaging, its label, name, color scheme, and the corporate identity in general (uniform, design of shopping space, window-dressing) or other elements that personalize the rival entity and its production.

All things considered, it can be concluded that the legislator acknowledges the content and significance of the right to corporate identity and provides it with protection. In terms of copyright, design and handing over of a booklet can be treated as a commissioning agreement with the following transfer of the rights to the customer. However, such an agreement is commonly qualified as a service one since its purpose is not producing a creative result (Art.1288 of the Civil Code of the Russian Federation) but development of a range of designations meeting the protectability criteria along with measurements contributing to individualization of the company and its goods in the market taking into consideration laws of marketing and sales promotion.

perts state that in the case a color is registered, its protection as a trade mark covers all the confusingly similar tones, even though a consumer will hardly distinguish "panton 485" from "panton 475" (Available at: http://www.vedomosti.ru/ technology/articles/2016/02/15/629398-sberbank-gazprom-mts).

${ }^{1}$ Russian Gazette. 2006. No. 162.
It is noteworthy that the formation of image, being seldom mentioned in statutory acts, appeared to be a subject matter in a Letter of the Ministry of Culture of the Russian Federation ${ }^{2}$. Recognizing the need for the formation of a theatre's corporate culture and identity as one of the most important marketing tasks in this sphere, the Ministry specifies that corporate identity of a theatre includes architectural (exterior decoration, interiors of the spectator area) and information design (emblem, logotype and all the advertising elements connected with them: playbills, tickets, booklets, leaflets, business correspondence, souvenirs, etc.) This design must be unique, recognizable and must reflect the specific character of the theatre. All the constituents of the theatre's identity must be interconnected by the internal conceptual unity and based on the esthetics originating from the creative activity of the theatre, its architectural and socio-cultural environment, conceptual aspects of its program.

One must not underestimate the use of corporate clothing, which is clothes with corporate colors and logotypes. Concerning Paragraph 2 of Clausel of Article 182 of the Civil Code of the Russian Federation, the court explained that the list of the examples of the environment provided there (a shop assistant, a cashier, etc.) is not complete. It also concerns employees who carry out particular transactions on behalf of the company in a certain place $^{3}$. Thus, it can be concluded that seeing a person wearing clothes which can be recognized as corporate ones, a consumer, a client or a potential counteragent has the right to believe that they are dealing with the representative of the company authorized to solve certain problems.

Signboards on a company's buildings are often presented in Russian law as a company's mean of individualization (element of brand identity) which is legally treated as a commercial designation, trade name and trademark, intellectual property (or possesses several legal statuses at the same time).

\footnotetext{
${ }^{2}$ The Letter of the Ministry of Finance of the Russian Federation of March 062012 No. 31-01-39/02-PX "On Approval of Methodological Recommendations on the Development of Theaters in Regions and Measures to Support Theaters". [Electronic resource]. Access from the information system "Ayudar Info".

${ }^{3}$ Decision of The Fourteenth Arbitration Court of February 5, 2013 on case No. A05-11666/2012. [Electronic resource]. Access from the information system «Judicial and Statutory Acts of the Russian Federation»».
} 
In the case a company's monopoly on its corporate image and identity is violated, provisions on protection of fair competition could be applied.

According to the law, the use of corporate identity of another company is the ground for bringing to responsibility for breaking norms of fair competition in the market.

\section{Image, Brand, Business Reputation, Commercial Goodwill}

According to a well-known quote by Philip Kotler: "The art of marketing is the art of brand building. If you are not a brand, you are a commodity". The widespread use of the word "brand" in marketing has led to the increasing number of researches on the problem of correlation between the concept of "brand" and the concept of mean of individualization of a good, work or work service.

The term "brand" takes its origin from the Norse "brandr", a word standing for a permanent mark used by cattle owners to mark their animals. Thus, in terms of consumerist psychology, brand is information stored in consumers' memory [12].

The main thing differentiating brand from image is the fact that brand is a name, term, symbol or design (or combination of these), designating a particular type of a product or service of a particular manufacturer and distinguishing it from goods and services of other producers [10]. It means that brand is always connected with the result of the business activity, the product being produced, not with the personality of the producer [27].

The same conclusions can be drawn from other well-known definitions of the concept of brand, which mention intangible combination of a product's properties (its name, packaging, price, history, reputation and the method of advertising) [28]. Brand is seen as a combination of impressions a consumer gets of a certain trademark [18;33].

In economic literature, this term is used as a generalizing characteristics, including a brandname and brand-image of the producer of goods and services [33]. Studying the correlation between these two concepts, S. A. Sudarikov notes that "brand" includes trademarks, trade names, business reputation and commercial goodwill [16]. Thus, in terms of law and economics, neither image nor brand are identified with the category mean of individualization or with such its kind as trademark.
Despite being the most essential part of brand, trademark is just an integral part of it while the concept of brand is much wider. For example, in practice a commercial designation, label on a good, a company's logotype and emblem are sometimes called non-protected brand ${ }^{1}$. Anyhow, in all cases branding is a marker of the company's production [3], not the company itself.

As law enforcement practice shows, in terms of public law, brand is associated with a product but not with its producer or retailer. Thus, a certain scheme of realization of goods determines the choice of the method for product pricing in accordance with the market segment in which the taxpayer operates. In a legal controversy, the court held it impossible to increase or decrease the price for products (in this particular case - cars) with respect to the level of prices the taxpayer applied to identical (homogeneous) goods (works, services) within a short period of time; the decision being based on Part 4 of Clause 2 of Article 40 of the Russian Tax Code. The judicial decision states that the prices for Hyundai cars shall not be compared with market prices for other brands since in the case the transfer pricing system is involved, according to which interdependent persons perform concerted action to arrange bulk purchase of Hyundai cars in order to resell these in the territory of the Russian Federation. In the period under consideration, there was no wholesale market of cars imported to the country's distributors by foreign manufacturers ${ }^{2}$.

The issues of branding goods also arise in the framework of antimonopoly regulation. For example, the problem of umbrella brands promotion and so-called "surrogate advertising" is still under discussion.

Different companies use umbrella brands to define the identity of their goods; but when they are promoted, there is a risk for the companies of being

\footnotetext{
${ }^{1}$ Here noteworthy is the verdict by the Presidium of the Krasnodar Regional Court: non-living premises are used by the sole proprietor P. under the brand "firm "<... " with the aim of performing economic activity" (Decision the Presidium of the Krasnodar Regional Court of October 28, 2015 on case No. 44г-1961/2015).

${ }^{2}$ Decision of the Supreme Court of the Russian Federation of January 20, 2016 No. 305-es15-17755 on case No. A40$50654 / 2013$. [Electronic resource]. Access from the information system «Judicial and Statutory Acts of the Russian Federation».
} 
accused of unfair "surrogate advertising". According to the marketing practice of surrogate advertising, when advertising of a certain product is restricted (with regard to the advertising method, timing and placing), it is replaced with advertising of another product having no restrictions and able to whet consumers' interest in the former product and promote it to the market ${ }^{1}$. This way so-called "umbrella brands" are advertised, these being trademarks which are identical or similar to each other, registered in different classes of the International Classification of Goods and Services and aimed at individualization of different goods and services [13]. However, the use of umbrella brands refers, first of all, to identification of a product but not its producer.

The concept of image is close to the concept of reputation; however, there is a difference. When applying a simplified approach, one can say that these concepts are fundamentally different: image is something you create by means of advertising while reputation is how people accept you [8].

Traditionally, business reputation is defined as an intangible benefit. At the same time, in some works it is pointed out that in developed systems of justice business reputation is seen as a valuable economic asset and rights to it are considered as a type of property. Following this approach, the European Human Right Court constantly applies regulations of Articlel of Protocol No. 1 to the Human Rights Convention, which protects the right to property, to business reputation and business relations (see, for example, cases Van Marle and others v. Netherlands, complaint No. 8543/79 or Buzescu v. Romania, complaint No. 61302/00) [5]. This approach can become beneficial for the given research as it allows us to see the cost of the brand, image and business reputation.

In accordance with RAS 14/2007 "Accounting for Intangible Assets", in records of a company being a buyer business reputation is taken into account provided the company's purchase value exceeds its net asset value ${ }^{2}$ (and it is the only case of reputation accounting). Thus, the general approach to assessing business reputation is reduced to per-

\footnotetext{
${ }^{1}$ Available at: http://www.fas.gov.ru/clarifications/clarifications_30337.html\#Art5 (accessed 29.07.2016).

${ }^{2}$ The Order of the Ministry of Finance of the Russian Federation of December 27, 2007 No. 153. Russian Gazette. 2008. 2 February.
}

forming purely mathematical calculations to determine a particular indicator affecting not only the balance structure and financial performance of the company but also decisions made by counteragents concerning further cooperation with this company (solid positive business reputation is undoubtedly advantageous in terms of future prospects) [9].

The research given regards the concept of "business reputation" as a company's reputation in the business environment. Nowadays, the following types of business reputation are distinguished: acquired and internally generated, positive and negative.

Acquired business reputation must be corrected within the period of twenty years (but no longer than the duration of the company); internally created business reputation is not subject to accounting; depreciation deductions on positive goodwill are reflected in accounting records of the company through reducing its initial cost; negative business reputation is attributed to financial results of the company as other incomes (Cl. 56 Order of the Ministry of Finance of the Russian Federation No. 34 of July 29, 1998 "On the Approval of Regulations on Bookkeeping and Accounting in the Russian Federation"3).

The use of a non-owned brand can damage to a company's business reputation. When assessing the damage caused to the brand, the attention is mainly focused not on the probability to confuse the designations but on piggybacking on non-owned business reputation and potential losses of consumers. The given approach is based on the idea that in modern conditions businessmen "develop their brands based not on the product but on reputation" [25].

According to M. A. Rozhkova and A. S. Vorozhevich, concepts of "goodwill" and "business reputation" are often identified with each other and used as synonyms [32; 23]. However, this idea is completely wrong as "goodwill" is a far wider category in terms of its content and only involves business reputation as its part (along with other elements) [7]. In its broadest sense, goodwill can be defined as a company's competitive advantage.

Goodwill as an asset is a benefit based on the probability that customers will continue visiting

\footnotetext{
${ }^{3}$ Bulletin of Normative Acts of Federal Executive Bodies. No. 23.1998. September 14.
} 
places of the business in the future; that where business success depends on the company's reputation, goodwill includes an advantage resulting from the right of the business owner to present himself as such; and that where business value depends on business contacts, goodwill gained when purchasing the business entitles the purchaser to using these contacts [26].

Thus, "image" appears to be a more general concept, including the concepts of "brand" and "goodwill" as its independent constituents (with goodwill, in its turn, including a company's business reputation).

\section{Conclusions}

The term "image" is increasingly used by the legislator and courts to define intangible assets of companies and sole proprietors, which demonstrates the necessity for this concept to be recognized as an independent legal concept.

In the case monopoly on a company's corporate image and identity is violated, regulations on the protection of fair competition could be applied.

According to legislation, the use of non-owned corporate identity is the reason for bringing a company to responsibility for violation of norms of fair competition in the market.

In modern conditions, for creation and protection of image (including elements of reputation, corporate identity) it is possible to use different procedures forming brand identity (primarily trade names, trademarks, commercial designations), institutions of intellectual property, and also measures to maintain market competition based on competition law.

"Image" appears to be a more general concept, including the concepts of "brand" and "goodwill" as its independent constituents (with goodwill, in its turn, including a company's business reputation).

\section{References}

1. Blinov O. A., Zakharov V. Ya. Imidzh organizatsii kak faktor ee konkurentosposobnosti [Image of an Organization as a Factor of Its Competitiveness]. Menedzhment $v$ Rossii $i$ za rubezhom - Management in Russia and Abroad. 2003. № 4. Pp. 35-44. (In Russ.).

2. Vyborova T. G. Formirovanie imidzha organizatsii sfery uslug: avtoref. diss. ... kand. ekon. nauk [Formation of the Image of a Service En- terprise: Synopsis of Dr. econ. sci. diss.]. Novosibirsk, 2012. 20 p. (In Russ.).

3. Gavrilov E. Sredstva individualizatsii tovarov $i$ kachestvennye kharakteristiki tovarov [Means of Individualization of Goods and Qualitative Characteristics of Goods]. Hozyajstvo i pravo - Business and Law. 2014. № 3. Pp. 13-27. (In Russ.).

4. Gersh M. V. Imidzh organizatsii [Image of an Organization]. Otdel kadrov kommercheskoj organizatsii - The Personnel Department of a Commercial Organization. 2015. № 7. Pp. 6468. (In Russ.).

5. Egorova M. A. Kommercheskoe pravo: uchebnik dlja vuzov [Commercial Law: Textbook for Universities]. Moscow, 2013. 640 p. (In Russ.).

6. Zashhita delovoj reputatsii $v$ sluchajakh ee diffamatsii ili nepravomernogo ispol'zovanija (v sfere kommercheskikh otnoshenij): nauchnoprakticheskoe posobie; pod red. M. A. Rozhkovoj [The Protection of Goodwill in Cases of Its Defamation or Misuse (in Commercial Relations): Scientific and Practical Guide; ed. by M. A. Rozhkova]. Moscow, 2015. 270 p. (In Russ.).

7. Imidzh - nichto, reputatsija - vse!!! (Interv'ju s A. Fisunom) [Image is Nothing, Reputation is Everything!!! (An interview with A. Fisun)]. Upravlenie personalom - Personnel Management. 2014. № 22. Pp. 25-33. (In Russ.).

8. Klimashina Ju.S. Al'ternativnyj podkhod $k$ uchetu delovoj reputatsii organizatsij [Alternative Approach to Accounting of Business Reputation of Organization]. Auditor - Auditor. 2015. № 10. Pp. 42-49. (In Russ.).

9. Kotler Ph. Marketing ot A do Ja: 80 konceptsij, kotorye dolzhen znat' kazhdyj menedzher [Marketing Insights from A to Z: 80 Concepts Every Manager Needs to Know]. Moscow, 2010. P. 19. (In Russ.).

10. Linjucheva M. V. Upravlenie imidzhem organizatsii $v$ sovremennykh rossijskikh uslovijakh: avtoref. kand. ... sotsiol. nauk [Management of the Organization's Image in Modern Russian Conditions: Synopsis of Dr. soc. sci. diss.]. Saratov, 2013. 22 p. (In Russ.).

11. Moiseev M. V. Brend - ob"ekt imushhestvennogo prava [Brand as an Object of the Property Right]. Aktual'nye voprosy bukhgalterskogo ucheta $i$ nalogooblozhenija - Current Issues of Accounting and Taxation. 2010. № 19. Pp. 6378. (In Russ.). 
12. Nastol'naja kniga rukovoditelja organizatsii: pravovye osnovy; otv. red. I. S. Shitkina [Handbook of the Head of an Organization: Legal Basics; ed. by I. S. Shitkina]. Moscow, 2015. 506 p. (In Russ.).

13. Smirnov A. V. Vlijanie tsennostej na protsess pertseptsii vneshnego imidzha organizatsii: avtoref. kand. ... psikhol. nauk [The Values' Influence on the Process of Perception of the External Image of the Organization: Synopsis of Dr. psych. sci. diss.]. Moscow, 2009. 21 p. (In Russ.).

14. Sudarikov S. A. Pravo intellektual'noj sobstvennosti: uchebnik [Intellectual Property Right: Textbook]. Moscow, 2010. 368 p. (In Russ.).

15. Sushkova T. V. Formirovanie imidzha banka v uslovijakh ekonomicheskoj nestabil'nosti: avtoref. diss. ... kand. ekon. nauk [Formation of the Image of the Bank in the Conditions of Economic Instability: Synopsis of Dr. econ. sci. diss.]. Penza, 2011. 22 p. (In Russ.).

16. Chernysheva A. M. Brending: uchebnik dlja bakalavra [Branding: Textbook for Bachelor students]. Moscow, 2014. 504 p. (In Russ.).

17. ACES: Documents for Small Firms. Available at: http://www.acec.org/ssoLinkage/?ssoToken =f96ba897-6656-416e-b61b-9a4680548f6e \& redirectURL=http://docs.acec.org/pub/DB6AF 220-023C-8E2C-B9FE-B0BC71F257E1\&Site $=$ ACEC (accessed 25.07.2016). (In Eng.).

18. Balmer J. M. T., Wilkinson A. Building Societies: Change, Strategy and Corporate Identity. Journal of General Management. 1991. Vol. 17. № 2 (winter). Pp. 20-33. (In Eng.).

19. Becker E. System des heutigen Pandektenrechts. 1886. 383 p. (In Ger.).

20. Böhlau H. Rechhtssubjekt und Personenrolle. Rostock, 1871. Pp. 3-33. (In Ger.).

21. Cohen T. European Trademark Law: Community Trademark Law and Harmonized National Trademark Law. Netherland, 2010. 728 p. (In Eng.).

22. Cornish W.R. Intellectual property: patents, copyright, trade marks and allied rights. London: Sweet \& Maxwell, 1996. 722 p. (In Eng.).

23. Desai D. R., Waller S. Brands, Competition and the Law. Available at: http://www.law2.byu. edu/lawreview4/archives/2010/5/01DesaiWaller. pdf. (accessed 25.06.2016). (In Eng.).

24. Dicksee L. R., Tillyard F. Goodwill and its Treatment in Accounts, $3 \mathrm{~d}$ ed. London, reprint- ed in "The 62 History of Accounting Collection", New York: Arno Press, 1976. 168 p. (In Eng.).

25. Kotler P., Kartajaya K., Setiawan I. Marketing 3.0: From Products to Customers to the Human Spirit. 2010. 208 p. (In Eng.).

26. Ogilvy D. Ogilvy on Advertising. 1985. 224 p. (In Eng.).

27. Olins $W$. Corporate Identity: Making Business Strategy Visible through Design. Harvard Business School Press, 1990. 224 p. (In Eng.).

28. Peter J. Booth. The Internet and Dispute Resolution. Available at: http://www.gordon andjackson.com.au/resources_uploads//documents/articles/The_Internet_and_Dispute_Resolution_Booth_paper_24_02_2011.pdf (accessed 25.06.2016). (In Eng.).

29. Resolution Question Q245. Taking unfair advantage of trademarks: parasitism and free riding. Congress Rio de Janeiro 2015 Adopted Resolution 14 October 2015. Available at: http://aippi.org/wp-content/uploads/2015/10/

2015-Resolution-Taking-unfair-advantage-oftrademarks-parasitism-and-free-riding-Q245. pdf (accessed 23.07.2016). (In Eng.).

30. Sakulin $W$. Trademark Protection and Freedom of Expression: an Inquiry into the Conflict between Trademark Rights and Freedom of Expression under European Law. Rotterdam, 2011. 382 p. (In Eng.).

31. Yelnik A. Commercial Value of Trade Marks: Do Current Laws Provide Sufficient Protection. European Intellectual Property Review. 2010. Vol. 32. Issue 5. Pp. 203-220. (In Eng.).

\section{References in Russian}

1. Блинов О. А. Захаров В. Я. Имидж организации как фактор ее конкурентоспособности // Менеджмент в России и за рубежом. 2003. № 4. C. 35-44.

2. Выборова Т. Г. Формирование имиджа организации сферы услуг: автореф. дис. ... канд. экон. наук. Новосибирск, 2012. 20 с.

3. Гаврилов Э. Средства индивидуализации товаров и качественные характеристики товаров // Хозяйство и право. 2014. № 3. С. 13-27.

4. Гери М. В. Имидж организации // Отдел кадров коммерческой организации. 2015. № 7. C. 64-68.

5. Егорова М. А. Коммерческое право: учебник для вузов. М.: РАНХиГС при Президенте РФ, Статут, 2013. 640 с. 
6. Защита деловой репутации в случаях ее диффамации или неправомерного использования (в сфере коммерческих отношений): науч.-практ. пособие / под ред. М. А. Рожковой. М.: Статут, 2015. 270 с.

7. Имидж - ничто, репутация - все!!! [Интервью с А. Фисуном] // Управление персоналом. 2014. № 22. С. 25-33.

8. Климашина Ю. С. Альтернативный подход к учету деловой репутации организаций // Аудитор. 2015. № 10. С. 42-49.

9. Котлер $Ф$. Маркетинг от А до Я: 80 концепций, которые должен знать каждый менеджер / пер. с англ. М.: Альпина Паблишерз, 2010. $211 \mathrm{c}$.

10. Линючева М.В. Управление имиджем организации в современных российских условиях: автореф. ... дис. канд. социол. наук. Саратов, 2013. $22 \mathrm{c}$.

11. Моисеев М. В. Бренд - объект имущественного права // Актуальные вопросы бухгалтерского учета и налогообложения. 2010. № 19. С. 63-78.

12. Настольная книга руководителя организации: правовые основы / отв. ред. И. С. Шиткина. М.: Юстицинформ, 2015. 506 с.

13. Смирнов А. В. Влияние ценностей на процесс перцепции внешнего имиджа организации: автореф. ... дис. канд. психол. наук. М., 2009. $21 \mathrm{c}$.

14. Судариков С. А. Право интеллектуальной собственности: учебник. М.: Проспект, $2010.368 \mathrm{c}$.

15. Сушкова Т. В. Формирование имиджа банка в условиях экономической нестабильности: автореф. дис. ... канд. экон. наук. Пенза, 2011. $22 \mathrm{c}$.

16. Чернышева А. М. Брендинг: учебник для бакалавра. М.: Юрайт, 2014. 504 с.

17. ACES: Documents for Small Firms. URL: http://www.acec.org/ssoLinkage/?ssoToken=f9 6ba897-6656-416e-b61b-9a4680548f6e\&redirectURL $=$ http://docs.acec.org/pub/DB6AF220023C-8E2C-B9FE-B0BC71F257E1\&Site $=$ AC ЕС (дата обращения: 25.07.2016).

18. Balmer J. M. T., Wilkinson A. Building Societies: Change, Strategy and Corporate Identity. Journal of General Management. 1991. Vol. 17. № 2 (winter). Pp. 20-33.
19. Becker E. System des heutigen Pandektenrechts. $1886.383 \mathrm{p}$.

20. Böhlau H. Rechhtssubjekt und Personenrolle. Rostock, 1871. S. 3-33.

21. Cohen T. European Trademark Law: Community Trademark Law and Harmonized National Trademark Law. Netherland, 2010. 728 p.

22. Cornish W.R. Intellectual property: patents, copyright, trade marks and allied rights. L.: Sweet \& Maxwell, 1996. 722 p.

23. Desai D. R., Waller S. Brands, Competition and the Law. URL: http://www.law2.byu.edu/ lawreview4/archives/2010/5/01DesaiWaller.pdf. (дата обращения: 25.07.2016).

24. Dicksee L.R., Tillyard F. Goodwill and its Treatment in Accounts, $3 \mathrm{~d}$ ed. London, reprinted in "The 62 History of Accounting Collection". New York: Arno Press, 1976. 168 p.

25. Kotler P., Kartajaya K., Setiawan I. Marketing 3.0: From Products to Customers to the Human Spirit (Inglese) Copertina rigida - $25 \mathrm{mag}$ 2010. $208 \mathrm{p}$.

26. Ogilvy on Advertising Paperback - March 12, 1985. $224 \mathrm{p}$.

27. Olins $W$. Corporate Identity: Making Business Strategy Visible through Design. Harvard Business School Press, 1990. 224 p.

28. Peter J. Booth. the Internet and Dispute Resolution. URL: http://www.gordonandjackson. com.au/resources_uploads//documents/articles/ The_Internet_and_Dispute_Resolution_Booth paper_24_02_2011.pdf (дата обращения: 25.06.2016).

29. Resolution Question Q245 Taking unfair advantage of trademarks: parasitism and free riding// Congress Rio de Janeiro 2015 Adopted Resolution 14 October 2015. URL: http://aippi. org/wp-content/uploads/2015/10/2015-Resolution-Taking-unfair-advantage-of-trademarks-parasitism-and-free-riding-Q245.pdf (дата обращения: 23.07.2016).

30. Sakulin $W$. Trademark Protection and Freedom of Expression: an Inquiry into the Conflict between Trademark Rights and Freedom of Expression under European Law. Rotterdam, 2011. $381 \mathrm{p}$.

32. Yelnik A. Commercial Value of Trade Marks: Do Current Laws Provide Sufficient Protection. European Intellectual Property Review. 2010. Vol. 32, issue 5. Pp. 203-220. 